\title{
ANATOMY, CELL WALL STRUCTURE AND TOPOCHEMISTRY OF WATER-LOGGED ARCHAEOLOGICAL WOOD AGED 5,200 AND 4,500 YEARS
}

\author{
Katarina Čufar ${ }^{1}$, Jožica Gričar ${ }^{1,2}$, Martin Zupančičc ${ }^{1}$, Gerald Koch ${ }^{3}$ and \\ Uwe Schmitt $^{3}$
}

\begin{abstract}
SUMMARY
Evaluating the state of deterioration of water-logged archaeological wood is necessary in order to select treatments for its conservation and storage, particularly in the case of valuable archaeological artefacts. For this purpose archaeological wood of ash (Fraxinus sp.) and oak (Quercus sp.) buried in water-logged conditions at prehistoric settlements on the Ljubljansko barje (Ljubljana moor), Slovenia, aged approx. 5,200 and 4,500 years, was investigated by means of light microscopy (LM), transmission electron microscopy (TEM) and cellular UV-microspectrophotometry (UMSP). LM and TEM revealed that the ash wood aged 5,200 years was the least preserved. The secondary walls of fibres, vessels and parenchyma cells were considerably thinner than in normal wood, indicating distinct degradation. TEM and UMSP additionally revealed strong delignification of the remaining parts of the secondary walls of all cell types. The compound middle lamellae appeared structurally intact, but had lower UV-absorbance than normal wood of the same species. The cell corners were topochemically unchanged, as shown by high analogue UV-absorbance. The UV-absorbance maxima at a wavelength of $278 \mathrm{~nm}$ corresponded to those of hardwood lignins. The oak heartwood was generally better preserved than the ash wood. Within each species, the 4,500year-old samples generally appeared better preserved than those 5,200 years old.
\end{abstract}

Key words: Archaeological wood, light microscopy, UV-microspectrophotometry, transmission electron microscopy, oak (= Quercus sp.), ash (=Fraxinus $\mathrm{sp}$.), cell wall, topochemistry.

\section{INTRODUCTION}

Wood from the distant past can be preserved under water or in water-logged conditions for centuries or even for millennia. In such cases, subfossil wood mainly originating

1) University of Ljubljana, Biotechnical Faculty, Department of Wood Science and Technology, Rožna dolina, Cesta VIII/34, SI-1000 Ljubljana, Slovenia [E-mail: katarina.cufar@bf.uni-lj.si].

2) Slovenian Forestry Institute, Večna pot 2, SI-1000 Ljubljana, Slovenia [E-mail: jozica.gricar@ gozdis.si].

3) Federal Research Centre for Forestry and Forest Products and University of Hamburg, Leuschnerstr. 91, D-21031 Hamburg, Germany [E-mail: g.koch@holz.uni-hamburg.de; u.schmitt@holz. uni-hamburg.de].

Associate Editor: Thomas Yanosky 
from fallen trees can generally be differentiated from archaeological wood previously used or modified by humans. When discovered, water-logged wood often appears surprisingly well preserved. Its conservation is of particular importance when valuable archaeological artefacts are found or when the wood and its tree rings represent a unique source of information on past environmental conditions, as well as on the culture and way of life of ancient peoples. Comprehensive information on archaeological wood has already been published (e.g. Rowel \& Barbour 1990). It was found that the properties and stage of deterioration vary considerably with soil conditions, age, wood species, position in the stem, history of wood use, fabrication etc. Oak (Quercus sp.) has been generally the most frequent and best investigated archaeological wood in Europe.

Numerous wooden artefacts in Europe from prehistoric pile dwellings in the Alpine area have been used for dendrochronological and dendroarchaeological investigations (e.g. Pétrequin et al. 1998; Billamboz 2003). The Ljubljansko barje (Ljubljana moor) in Slovenia is an area in the SE Alpine region with water-logged wood from different periods. In the last decade, systematic dendrochronological investigations and radiocarbon analyses have helped to determine the approximate age of these dwellings (Velušček \& Čufar 2002).

The majority of the pile dwellings in the Ljubljansko barje existed 5,500 to 4,500 years ago. The wood preserved until today mainly originates from piles that were placed vertically into the ground, and upon which the dwellings were then built. Valuable objects have occasionally been found, such as bows, canoes, and - as the most important archaeological artefact in this area - a wheel with axle aged approx. 5,200 years, made of ash and oak wood (Velušček 2002). It is particularly important for the conservation of such objects to know the specific properties of the wood of which they are made.

Previous investigations of water-logged archaeological wood from different sites have shown that, compared to fresh material, such wood has considerably reduced density, increased maximum moisture content, as well as increased proportion of lignin compared to celluloses and hemicelluloses (e.g. Florian 1990; Schniewind 1990; Čufar et al. 2002). Kim and Singh (2000) reviewed the micromorphological characteristics of wood biodegradation in a wet environment, describing also water-logged and buried archaeological wood. Cell wall decay by bacteria has been variously described (e.g. Schmidt 1980; Schmidt \& Liese 1982, 1994; Schmitt \& Hoffmann 1998; Björdal et al. 1999, 2000, 2005; Björdal \& Nilsson 2002; Singh et al. 2003). Among the cell-wall degrading bacteria, the erosion bacteria seemingly have the greatest role in decomposition of buried or water-logged wood (e.g. Donaldson \& Singh 1990; Blanchette et al. 1990; Singh \& Butcher 1991; Kim \& Singh 1994; Björdal et al. 1999). The changes in wood are closely related to changes in cell wall structure (Florian 1990; Schmitt \& Hoffmann 1998; Björdal et al. 1999, 2000, 2005; Singh et al. 2003). However, topochemical studies using cellular UV-microspectrophotometry (UMSP) to provide detailed information on cell wall degradation have not been previously used to evaluate changes in archaeological wood.

The purpose of this study was to investigate the cell wall structure and topochemistry of selected 5,200 and 4,500-year-old archaeological ash (Fraxinus sp.) and oak (Quercus sp.) using light microscopy (LM), transmission electron microscopy (TEM) and 
cellular UV-microspectrophotometry (UMSP). Understanding the degraded structure of archaeological wood is needed to prevent its immediate deterioration and to plan proper treatments for its long-term conservation and storage.

\section{MATERIAL AND METHODS}

The wood originated from two Eneolithic (copper age) settlements on Ljubljansko barje, i.e. Stare Gmajne (aged approx. 5,200 years) and Založnica (aged approx. 4,500 years). In both cases, the wood was buried in soil under water-logged conditions. Samples were taken from a larger collection of wood previously used for wood identification, dendrochronology, investigations of wood properties, and for radiocarbon dating (Čufar et al. 2002; Velušček \& Čufar 2002). The samples were stored in water-logged condition in vacuum packed bags of thick polyethylene at a temperature of approx. $13^{\circ} \mathrm{C}$. Such storing enables conservation or reuse of wood for further research. For the oak samples, analyses were carried out on outer heartwood rings, which were better preserved than the sapwood. In the case of ash, which does not contain darkly coloured heartwood, the wood appeared to be uniformly preserved throughout the stem, and the samples were taken from the outermost part of the stem discs.

For light microscopy, sample blocks $(1 \times 1 \times 1.5 \mathrm{~cm})$ were embedded in polyethylene glycol (PEG) 1500 with prior infiltration in a graded series of PEG/water solutions (20\%, $50 \%, 75 \%$ and $100 \%$ ) at a temperature of $60^{\circ} \mathrm{C}$. The duration of infiltration in each solution was approx. 72 hours. The embedding was considered completed when the cell lumina were filled with PEG. Then the samples were air dried at room temperature. Transverse sections (10-20 $\mu \mathrm{m}$ thick) were prepared using a Leica SM 2000R sliding microtome with steel knives. After removal of residual PEG with water, the sections were double-stained with an aqueous solution of safranin and astra blue, dehydrated using a graded series of ethanol $(50 \%, 70 \%$ and $95 \%)$ and mounted on glass slides with Euparal.

Parallel sample blocks $(2 \times 2 \times 3 \mathrm{~mm})$ were embedded in paraffin using a Leica TP 1020-1 tissue processor for dehydration in a graded series of ethanol (70\%, $90 \%, 95 \%$ and $100 \%$ ) and bio-clear (D-limonene) for paraffin infiltration (Rossi et al. 2006). Cross sections of $12 \mu \mathrm{m}$ thickness were prepared on a Leica RM 2245 rotary microtome, using disposable Feather N35H blades. For better adhesion of the sections, slides were pre-treated with albumin. Sections were dried at $70^{\circ} \mathrm{C}$ for one hour and cleaned of residual paraffin by immersing the slides in bio-clear and ethanol. Sections were finally stained for conventional light microscopy with safranine and astra blue dissolved in ethanol, or for UV-microscopy in chrysoidine-acridine red and astra blue.

In both cases, the dehydrated sections were mounted on glass slides using Euparal and examined with a Nikon Eclipse E800 light microscope in transmission and polarised light modes. Samples stained with chrysoidine-acridine red and astra blue were used for UV-fluorescence microscopy using blue UV-illumination provided by a combination of a 450-490 nm exciter filter and a $520 \mathrm{~nm}$ barrier filter. The dimensions of cell walls were determined for archaeological wood and for normal wood from the collection by Nikon Eclipse E800 microscope and Lucia G 4.8 image analysis system or by Olympus AX 70 microscope and Analysis 5.0 image analysis system. 
The sample blocks $(2 \times 2 \times 3 \mathrm{~mm})$ selected for transmission electron microscopy (TEM) analyses and UV-microspectrophotometry (UMSP) were dehydrated in a graded series of ethanol (70\%, 90\%, 95\% and 100\%) and water-free acetone and embedded in Spurr's epoxy resin (Spurr 1969). For TEM, ultrathin transverse sections (80-100 $\mathrm{nm}$ thick) were stained with potassium permanganate according to Donaldson (1992). Examination was carried out with a Philips CM 12 TEM at accelerating voltages of 40 or $60 \mathrm{kV}$ to enhance contrast. For UV-microspectrophotometric measurements, unstained transverse sections ( $1 \mu \mathrm{m}$ thick) were prepared from epoxy resin embedded samples, transferred to quartz slides, immersed in a drop of non-UV absorbing glycerine, and covered with quartz cover slips. The analyses were carried out using a Zeiss UMSP 80 microspectrophotometer equipped with a scanning stage, which enables the determination of image profiles at defined wavelengths with scan software APAMOS ${ }^{\circledR}$ (Zeiss). Lignin and phenolic extractives of archaeological wood were detected at a wavelength of $278 \mathrm{~nm}$. The scan programme digitises rectangular fields on the tissue with a local geometrical resolution of $0.25 \times 0.25 \mu \mathrm{m}$ and photometric resolution of 4096 grey scale levels, which are converted into 14 basic colours to visualise the absorbance intensities (Koch \& Kleist 2001; Koch \& Grünwald 2004). The scans can be depicted as two- or three-dimensional image profiles, including a statistical evaluation (as histogram) of the UV absorbance.

Photometric point by point measurements were also performed with a spot size of $1 \mu \mathrm{m}^{2}$ between $240 \mathrm{~nm}$ and $400 \mathrm{~nm}$ wavelengths, using the programme LAMWIN ${ }^{\circledR}$ (Zeiss). Measurements were automatically repeated 50 times for each point analysis. Spectra were taken from the cell walls, cell corners and deposits in the lumina of vessels, fibres and axial, as well as ray parenchyma in early- and latewood portions.
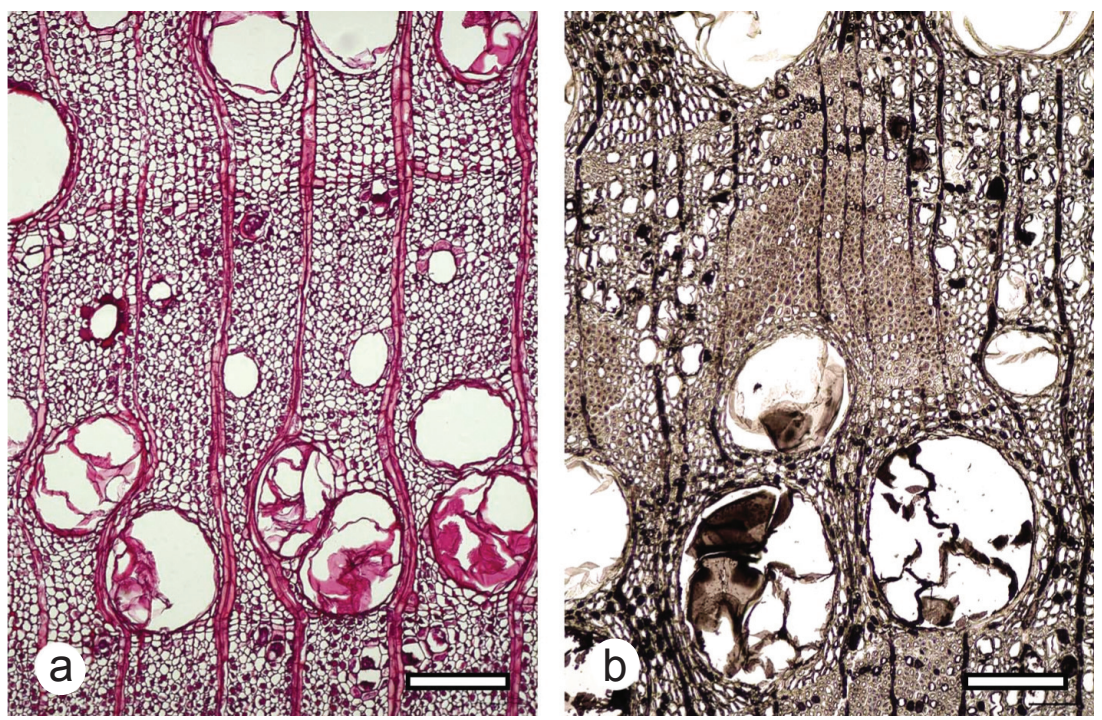

Figure 1. Light micrographs of transverse sections of a: 5,200-year-old archaeological ash (Fraxinus excelsior), and b: 4,500-year-old oak (Quercus sp.); embedding in PEG. - Scale bars $=200 \mu \mathrm{m}$. 


\section{RESULTS AND DISCUSSION}

Embedding of more or less intensely degraded archaeological wood in PEG or paraffin, with subsequent sectioning with a sliding or rotary microtome, provided high quality sections for light microscopic investigations (LM) and for wood identification (Fig. 1). The structure of vessels, axial parenchyma cells, various types of fibres and ray parenchyma cells, as well as pits, tyloses and other anatomical features, could be analysed without difficulty. LM in transmission and polarised light mode, as well as UV-fluorescence, was used for assessment of the degree of wood preservation (Fig. $2 \& 3$ ).
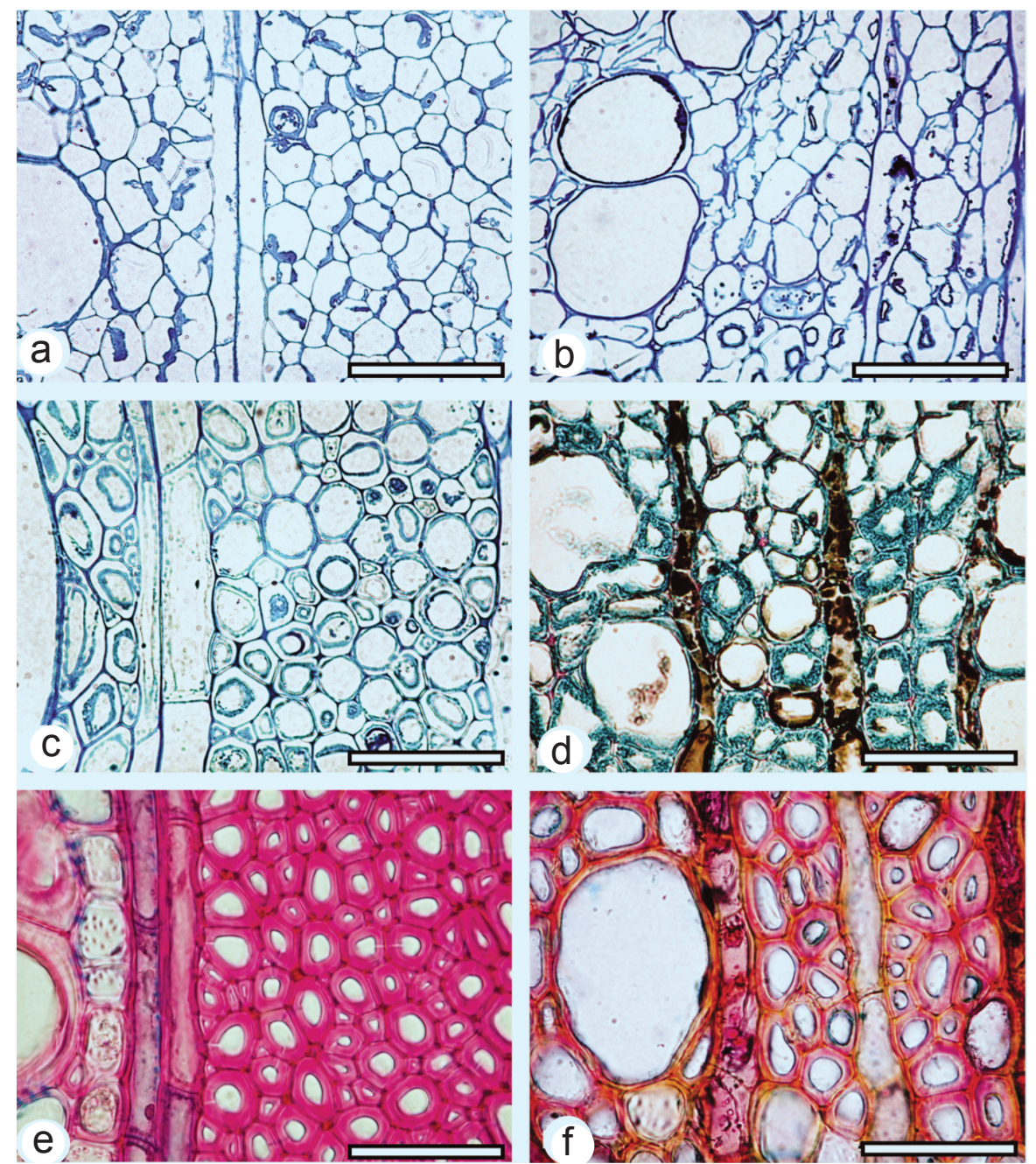

Figure 2. Light micrographs of transverse sections of archaeological and normal ash (Fraxinus excelsior) and oak (Quercus sp.) - a: 5,200-year-old ash. - b: 5,200-year-old oak. - c: 4,500year-old ash. - d: 4,500-year-old oak. - e: Undegraded ash. - f: Undegraded oak. - Scale bars $=$ $50 \mu \mathrm{m}$. 

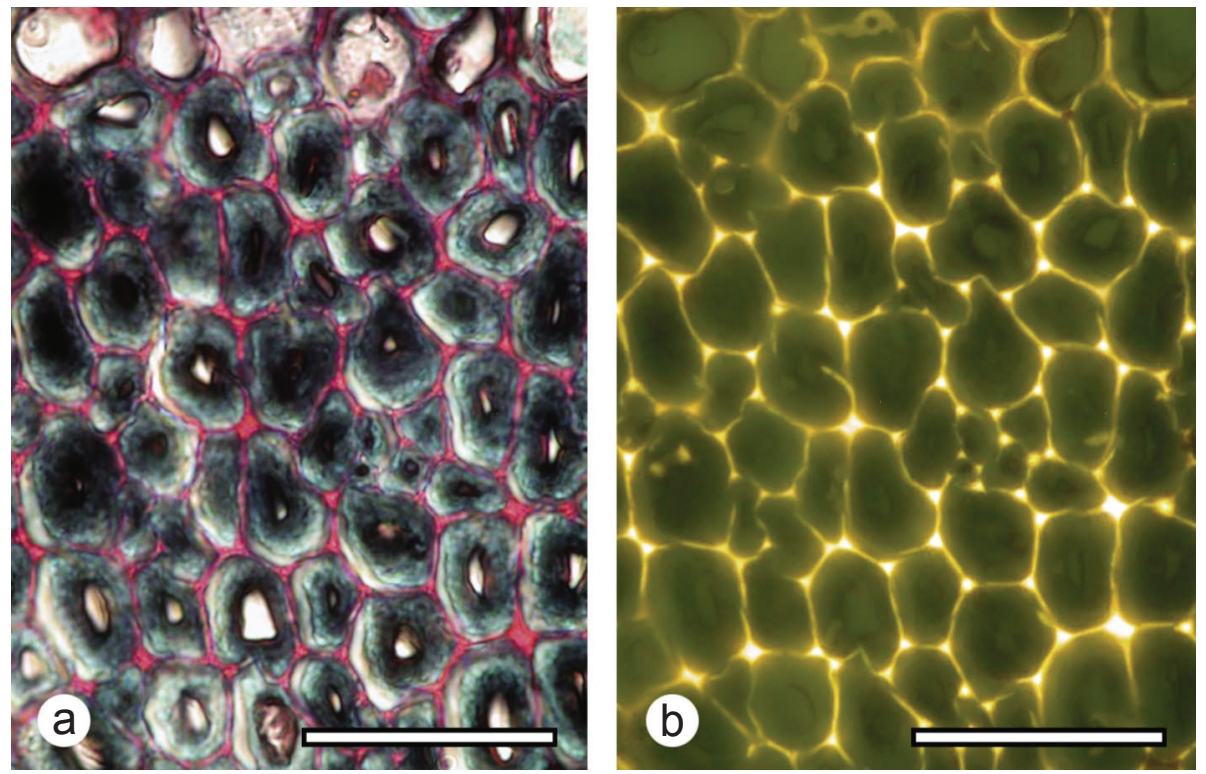

Figure 3. Transverse sections of 4,500-year-old archaeological oak (Quercus sp.). - a: Polarised light. - b: UV fluorescence. - Scale bars $=25 \mu \mathrm{m}$.

\section{Light and transmission electron microscopy}

The 5,200-year-old ash (shortly older ash) was the most degraded of all the excavated specimens. The average thickness of its fibre walls was less than $1 \mu \mathrm{m}$ (undegraded wood $3 \mu \mathrm{m}$ ) (Fig. 1a, 2a, e). The secondary wall was either absent or only partly preserved. The vessel walls were $\approx 1 \mu \mathrm{m}$ thick (undegraded wood up to $5 \mu \mathrm{m}$ ) (Fig. 2a, e). Tyloses and inclusions in tyloses, as well as phenolic deposits in the lumina of vessels, were frequently observed (Fig. 1a). The 4,500-year-old ash (shortly younger ash) appeared better preserved than the older ash. The thickness of fibre walls was below $1 \mu \mathrm{m}$. Most fibres still contained remains of secondary walls, although mostly detached from the compound middle lamella (CML); their thickness was on average about $2 \mu \mathrm{m}$ (Fig. 2c).

The 5,200-year-old oak (shortly older oak) generally was better preserved than the ash of the same age (Fig. 2b). The thickness of the remaining fibre walls, containing only the CML, was also below $1 \mu \mathrm{m}$ (undegraded wood $4 \mu \mathrm{m}$ ) (Fig. 2b, f). Most fibres contained secondary wall layers that were detached from the CML. The detached remains of the secondary wall were on average $2 \mu \mathrm{m}$ thick.

The tissue of the 4,500-year-old oak (shortly younger oak) was the best preserved archaeological wood (Fig. 1b, 2d). The wall thickness of fibres was on average $4 \mu \mathrm{m}$. Although the fibre thickness resembled that of normal wood (Fig. 2d, f), it was observed that their secondary walls had almost entirely lost birefringence and, additionally, did not fluoresce (Fig. 3a, b). 
Examinations with polarised light demonstrated that secondary wall cellulose, which occurs in undegraded walls as crystalline units, highly ordered in parallel aligned fibrils, lost its typical birefringence, indicating their disintegration. Although hemicelluloses are described as preferentially hydrolysed polysaccharides, celluloses also become depolymerised, thereafter leading to a granular appearance of the entire secondary wall (Diaz-Vaz et al. 1991). The lignin concentration in secondary wall portions also be-
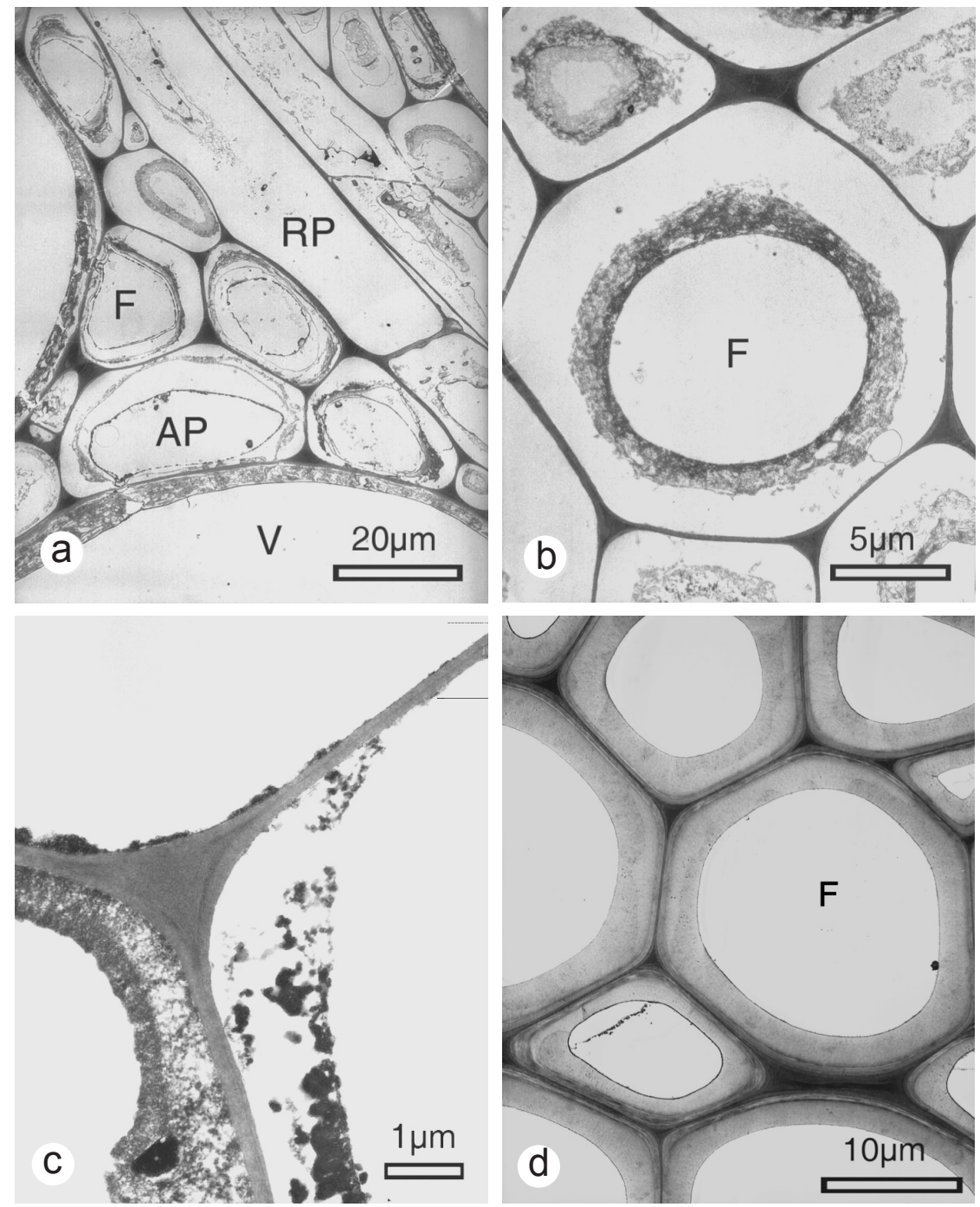

Figure 4. TEM micrographs of transverse sections of ash (Fraxinus excelsior). - a: All cell types in wood aged 4,500 years. - b: Fibres in wood aged 4,500 years. - c: Cell corners with dark stained compound middle lamella and partly preserved secondary wall in wood aged 5,200 years. $-\mathrm{d}$ : Fibres in undegraded wood. $-\mathrm{AP}=$ axial parenchyma, $\mathrm{F}=$ fibre, $\mathrm{RP}=$ ray parenchyma, $\mathrm{V}=$ vessel. 

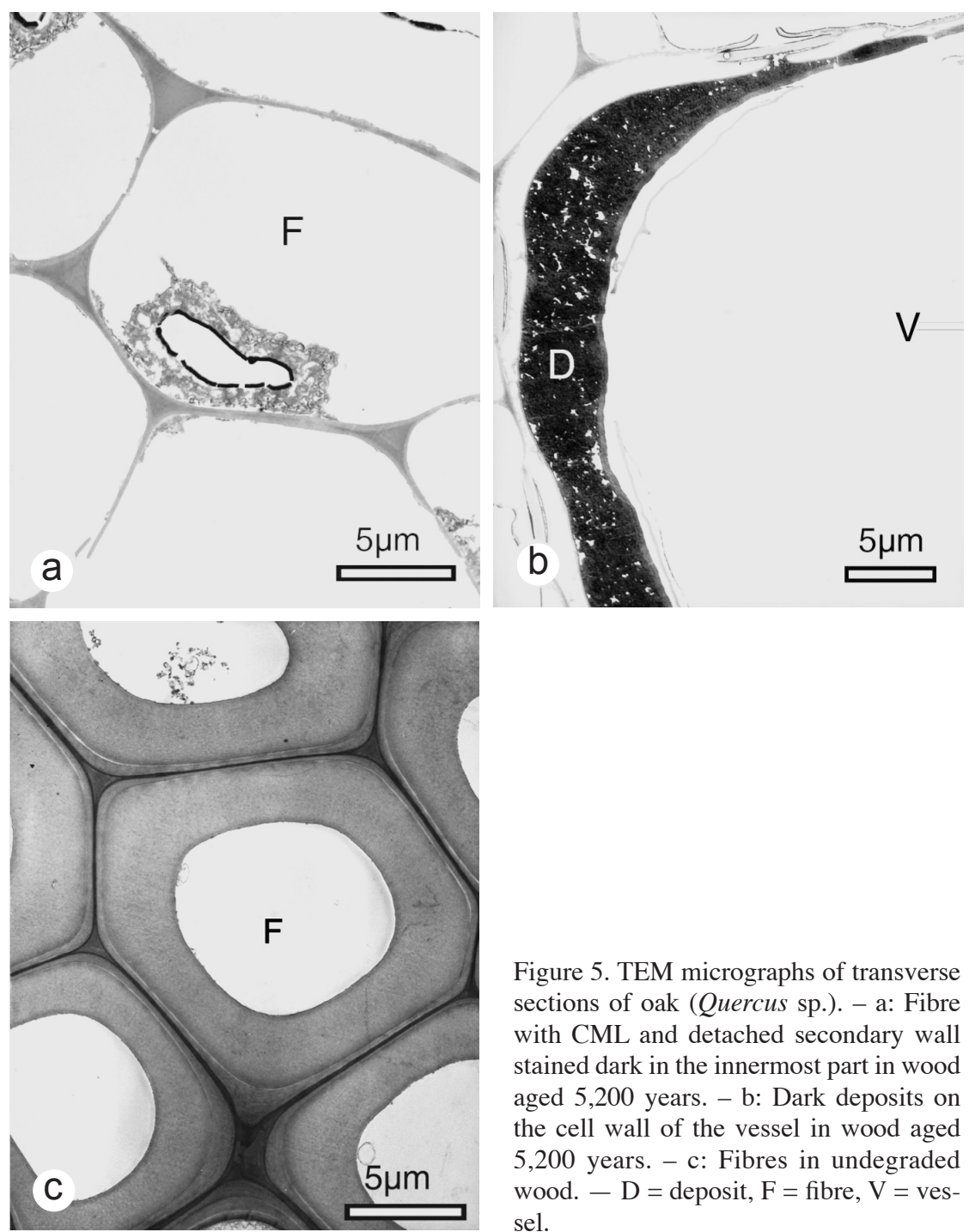

Figure 5. TEM micrographs of transverse sections of oak (Quercus sp.). - a: Fibre with CML and detached secondary wall stained dark in the innermost part in wood aged 5,200 years. - b: Dark deposits on the cell wall of the vessel in wood aged 5,200 years. $-\mathrm{c}$ : Fibres in undegraded wood. $-\mathrm{D}=$ deposit, $\mathrm{F}=$ fibre, $\mathrm{V}=$ vessel.

comes distinctly reduced, as indicated by the loss of fluorescence in CML portions, where lignin obviously remained in high concentrations. Such a structural pattern, with secondary walls showing distinct lignin loss, is well-known from archaeological wood and has been described in the literature as dissolution of lignin after abiotic degradation of polysaccharides (e.g. Hoffmann et al. 1986; Diaz-Vaz et al. 1991).

These structural observations therefore confirm earlier studies on the role of abiotic processes of degradation of cell wall compounds in archaeological wood (review: Kim \& Singh 2000). However, our light and electron microscopic analyses showed no evidence of bacterial wood decay as revealed in numerous archaeological woods 
(e.g. Schmidt \& Liese 1982, 1994; Blanchette et al. 1990; Singh \& Butcher 1991; Kim \& Singh 1994, 2000; Björdal et al. 1999, 2000, 2005; Schmitt et al. 2005).

Transmission electron microscopy (TEM) revealed that in the least preserved, older ash, the cell walls in most cases only consisted of the remaining compound middle lamella (CML), which appeared well preserved in all cell types. Remnants of severely deteriorated secondary walls could only be observed in some fibres (Fig. 4c). The dark colour of the CML stained with potassium permanganate indicated that lignin or ligninlike compounds are probably the main constituents of the remaining cell walls. The remnants of the secondary wall additionally appeared granular without retaining a fibrillar structure. Some fibres contained aromatic deposits in the lumina, which appeared as parts of the degraded walls. The walls of axial and radial parenchyma cells, as well as vessels, showed similar wall-degradation patterns. The lumina of parenchyma cells often contained inclusions.

In the younger ash, the fibre walls showed structurally intact CML portions, whereas secondary wall layers were detached from it, forming circular features in the lumina (Fig. 4a, b). In some fibres, the lumen side of the detached secondary walls stained dark (Fig. 4b). The vessel walls were only slightly thinner than in undegraded wood, with clearly visible CML and secondary wall, but the secondary wall portions were not darkly stained, indicating severe degradation (Fig. 4a). Axial and radial parenchyma cells also revealed degraded walls, with mostly detached secondary wall layers (Fig. 4a). This all indicates considerable cell wall degradation as compared to normal wood (Fig. 4d).

In the older oak, the cell walls of fibres were also mainly composed of a remaining CML and detached parts of secondary walls and were partly characterised by dark staining on the lumen side (Fig. 5a; compare to undegraded wood, Fig. 5c).

The walls of the vasicentric tracheids, parenchyma cells and vessels primarily consisted only of the remaining CML. Darkly stained inclusions were frequently present in the vessels (Fig. 5b) or in the lumina of other cell types. The younger oak apparently had less degraded cell walls. The fibres still had secondary walls that appeared grainy and often were detached or had dark inclusions on the lumen side. In other cell types, such as the vasicentric tracheids, parenchyma cells and vessels, phenolic inclusions were frequently deposited in the lumina or the cell walls.

\section{Distribution of lignin and phenolic extractives in archaeological wood}

The topochemical distribution and semi-quantitative determination of lignin and phenolic extractives in the tissue of archaeological wood were analysed by means of scanning UV-microspectrophotometry. The applicability of this technique for the topochemical detection of lignin within individual cell wall layers of several hardwoods and phenolic deposits has been demonstrated by different studies (e.g. Koch \& Kleist 2001; Koch et al. 2006). Figure 6 shows representative UV scanning profiles of 5,200year-old oak (Fig. 6a, b) and 5,200-year-old ash (Fig. 6c) at a defined wavelength of $278 \mathrm{~nm}$ (absorbance maximum of hardwood lignin). Evaluation of the scanning profiles of both tissues revealed strong delignification of the remaining and detached secondary wall layers of all cell types, as indicated by low absorbance values in the range of abs. 0.15 to 0.25 . 

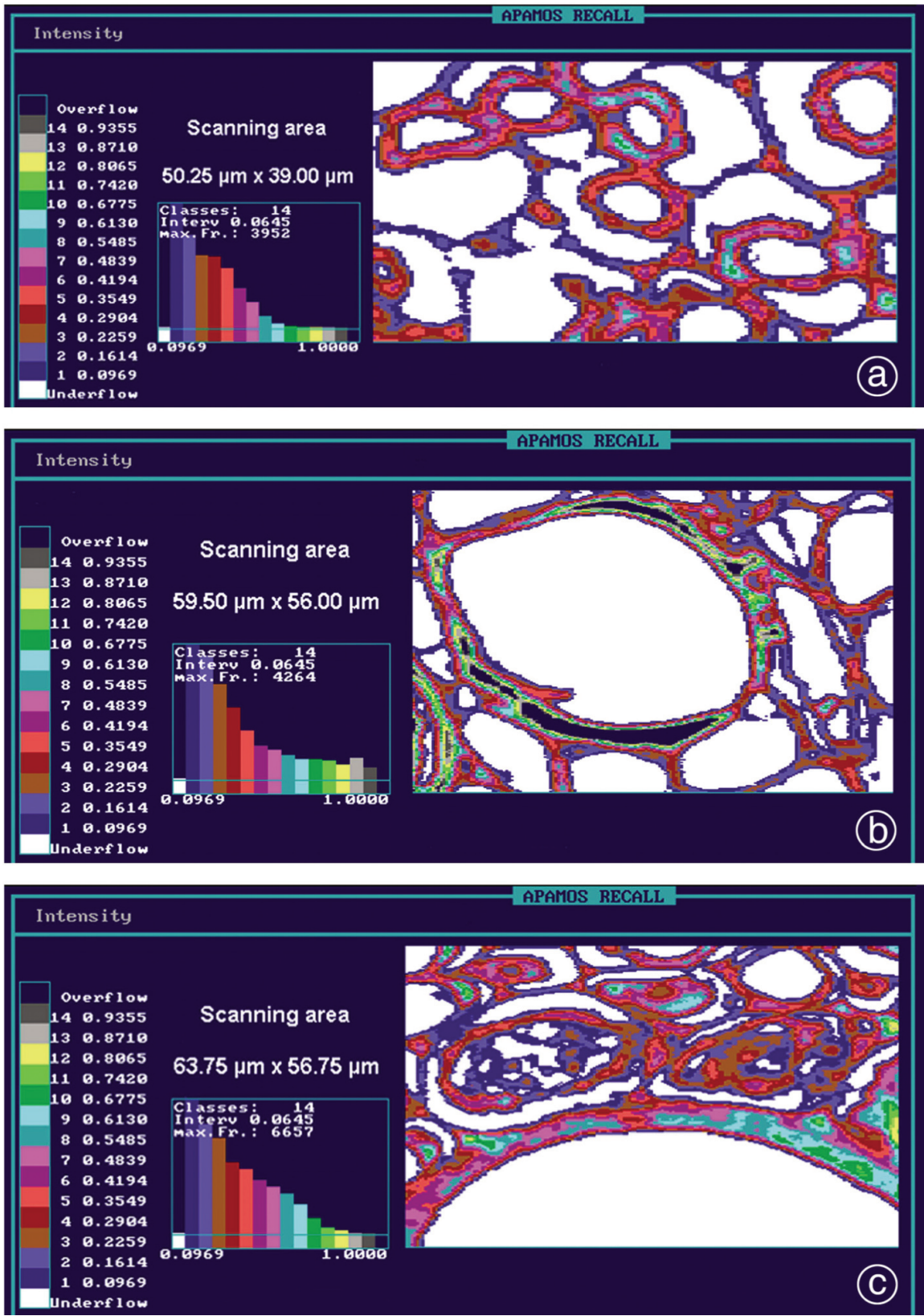

Figure 6. UV micrographs of cell wall layers and inclusions in the lumina of a \& b: 5,200year-old oak, and c: 5,200-year-old ash. Colour pixels indicate different intensities of UV absorbance at wavelength $\lambda 280 \mathrm{~nm}$ with a local geometrical resolution of $0.25 \mu \mathrm{m}^{2}$ per pixel. The cell walls show generally decreased UV absorbance, indicating delignification. The absorbance generally decreases from the cell corner and compound middle lamellae to the lumen. The inclusions in the lumina have similar absorbance values as those of the cell wall. 
The CMLs of all cell types were structurally well preserved, but were characterised further by significantly reduced UV-absorbance as compared with control cells of the same species. The cell corners characteristically remained unchanged, showing the high UV-absorbance values typical of undegraded oak and ash wood. In fibres, parenchyma cells and vessels, UV-absorbances generally decreased from the cell corner and CMLs to the lumina (Fig. 6). Furthermore, deposits of phenolic extractives could be detected in all cell types of the 5,200-year-old samples. The extractives were located in the lumina of the parenchyma cells and within the cell walls of vessels and tyloses. These compounds are characterised by relatively high absorbances in the range of 0.65 to 1.0 (overflow), as compared to the lower absorbances of the individual cell wall layers.

The lignification of individual cell wall layers of the archaeological wood was also examined by UV-microspectrophotometry at a wavelength range from 240 to $400 \mathrm{~nm}$. Figure 7 shows representative UV-absorbance spectra of a cell corner and the remaining $\mathrm{S}_{2}$ layer of a fibre, as well as phenolic deposits in vessels of the 5,200-year-old ash relative to the corresponding absorbance spectra of undegraded ash tissue. The UVspectra of the cell corner from archaeological ash wood show the typical absorbance behaviour of a recent hardwood lignin, with a distinct maximum of $\mathrm{abs}_{278 \mathrm{~nm}} 0.55$ at $278 \mathrm{~nm}$ and a local minimum at about $250 \mathrm{~nm}$ (Fergus \& Goring 1970; Takabe et al. 1992). In contrast, the spectra of the remaining $S_{2}$ layer display a distinctive decrease of absorbance values $\left(a_{2} s_{278 m}\right.$ 0.07) as compared to the values of the recent $S_{2}$ layer $\left(a_{278} \mathrm{~nm} 0.28\right)$. Phenolic deposits in the vessels of archaeological ash wood are characterised by much higher absorbance values $\left(\log \operatorname{abs}_{278 \mathrm{~nm}} 0.75\right)$ than those of cell wall associated lignins. Furthermore, their absorbance maxima display a bathochromic shift

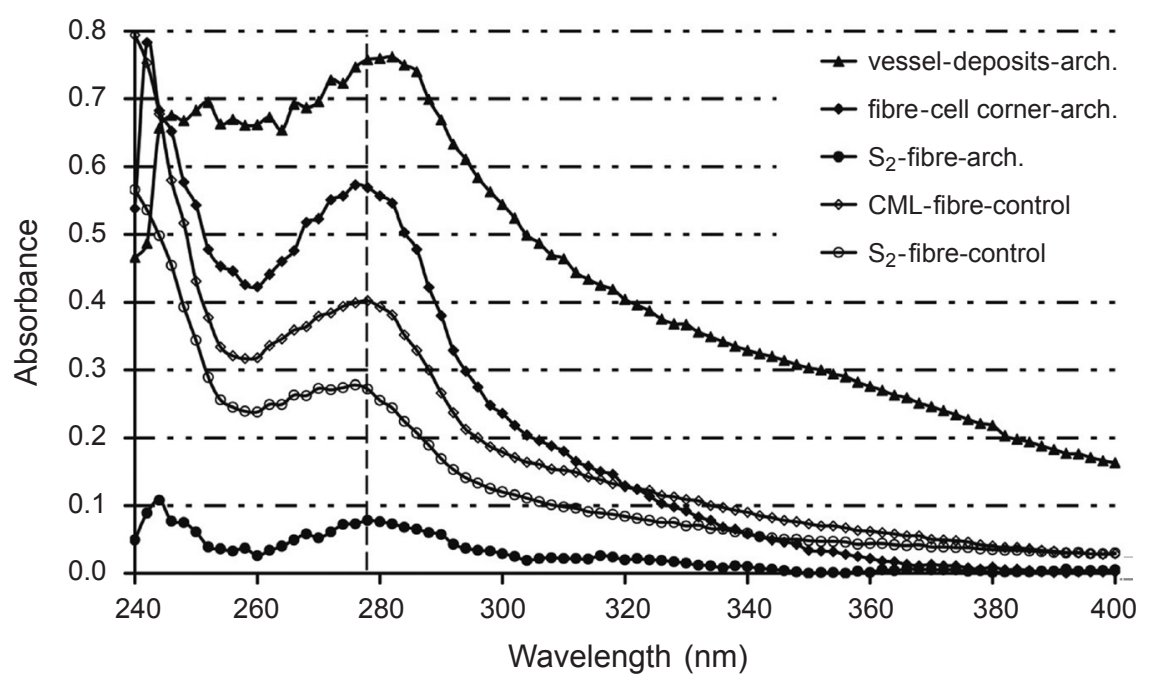

Figure 7. Representative UV absorbance spectra of individual cell wall layers $\left(\mathrm{S}_{2}\right.$ and cell corner of a fibre in 5,200-year-old and undegraded ash wood) and phenolic deposits in the vessel lumen (wavelength ranges between 240 and $400 \mathrm{~nm}$ ). 
to a wavelength of $284 \mathrm{~nm}$ and a slight shoulder at a wavelength range of $320 \mathrm{~nm}$. This spectral behaviour can be explained by the presence of chromophoric groups, such as conjugated double bonds attributed to highly condensed phenolics, as previously described for discoloured beech wood (Koch et al. 2003; Koch 2004).

UMSP analysis of the younger ash showed that the cell walls were generally better preserved and more lignified than those of the older ash, most likely due to phenolic compounds that contribute to high natural durability of oak heartwood. A separation of the innermost and outermost parts of the cell wall material is noticeable. The younger oak showed the least delignification of cell walls.

\section{CONCLUSIONS AND IMPORTANCE OF THE RESULTS FOR ARCHAEOLOGY AND CONSERVATION PRACTICE}

- The applied light- and electron microscopic techniques, as well as UV-spectrophotometry, revealed a common degradation pattern of the cell walls in archaeological wood from Ljubljansko barje.

- Degradation occurred primarily in secondary wall portions, with distinct degradation of polysaccharides and lignin removal.

- The observations confirmed differences in the degree of degradation with regard to wood species (ash and oak) and age (5,200 and 4,500 years).

- All categories of the investigated archaeological woods are severely degraded, with a high risk of deteriorating entirely within a short period.

- High rates of degradation explain differences in the properties of archaeological wood relative to typical wood.

- The structural and topochemical results help to better understand previous findings that wood from the same archaeological site showed considerably reduced density, increased maximum moisture content, and increased proportion of lignin in relation to cellulose (e.g. Čufar et al. 2002).

- The structure of the samples is consistent with abiotic rather than bacterial degradation.

- The most degraded sample was the 5,200-year-old ash, in which the remaining cell wall was composed only of a compound middle lamella; the heartwood of oak of the same age was only slightly better preserved.

- These findings are important for the recently excavated 5,200-year-old prehistoric wheel and axle made of ash and oak (Velušček 2002). Because this artefact is the oldest or one of the oldest preserved wheels in the world, the current study will help to better understand its vulnerability when selecting procedures for its preservation.

\section{ACKNOWLEDGEMENTS}

This study was supported by the Ministry of Higher Education, Science and Technology of the Republic of Slovenia, Research Program "Lesarstvo". We thank Tanja Potsch for her great help in the laboratory, Christina Waitkus for preparation of the figures, as well as two anonymous referees for their comments that have helped a lot to improve the manuscript. 


\section{REFERENCES}

Billamboz, A. 2003 Tree rings and wetland occupation in Southwest Germany between 2000 and 500 BC: Dendrochronology beyond dating in tribute to F.H. Schweingruber. Tree-Ring Research 59: 37-49.

Björdal, C.G., G. Daniel \& T. Nilsson. 2000. Depth of burial, an important factor in controlling bacterial decay of waterlogged archaeological poles. Int. Biodet. Biodeg. 45: 15-26.

Björdal, C.G. \& T. Nilsson. 2002. Waterlogged archaeological wood - a substrate for white rot fungi during drainage of wetlands. Int. Biodet. Biodeg. 50: 17-23.

Björdal, C.G., T. Nilsson \& S. Bardage. 2005. Three-dimensional visualisation of bacterial decay in individual tracheids of Pinus sylvestris. Holzforschung 59: 178-182.

Björdal, C.G., T. Nilsson \& G. Daniel. 1999. Microbial decay of waterlogged archaeological wood found in Sweden - applicable to archaeology and conservation. Int. Biodet. Biodeg. 43: 63-73.

Blanchette, R. A., T. Nilsson, G.F. Daniel \& A. Abad. 1990. Biological degradation of wood. In: R.M. Rowell \& R. J. Barbour (eds.), Archaeological wood. Properties, chemistry, and preservation: 147-174. Amer. Chem. Soc., Washington D.C.

Čufar, K., V. Tišler \& Ž. Gorišek. 2002. Arheološki les - njegove lastnosti in raziskovalni potencial (Archaeological wood - its properties and research potential). Arheološki Vestnik 53: 69-76.

Diaz-Vaz, J.E., U. Schmitt, M. Ruetze, T. Dillehay, J. Bremer \& O. Faix. 1991. Microscopy and analytical pyrolysis of Paleowood from Nothofagus dombeyi and Amomyrtus luma. Holzforschung 45: 407-414.

Donaldson, L.A. 1992. Lignin distribution during latewood formation in Pinus radiata. IAWA J. 12: 381-387.

Donaldson, L.A. \& A.P. Singh. 1990. Ultrastructure of Terminalia wood from an ancient Polynesian canoe. IAWA Bul. n.s. 11: 195-202.

Fergus, B.J. \& D. A.I. Goring. 1970. The distribution of lignin in birch wood as determined by ultraviolet microscopy. Holzforschung 24: 118-124.

Florian, M.L.E. 1990. Scope and history of archaeological wood. In: R.M. Rowell \& R. J. Barbour (eds.), Archaeological wood. Properties, chemistry, and preservation: 3-32. Amer. Chem. Soc., Washington D.C.

Hoffmann, P., R.D. Peek, J. Puls \& E. Schwab. 1986. Das Holz der Archäologen - Untersuchungen an 1600 Jahre altem wassergesättigtem Eichenholz der "Mainzer Römerschiffe". Holz RohWerkst. 44: 241-247.

Kim, Y.S. \& A.P. Singh. 1994. Ultrastructural aspects of bacterial attacks on a submerged ancient wood. Mokuzai Gakkaishi 40: 554-562.

Kim, Y.S. \& A.P. Singh. 2000. Micromorphological characteristics of wood biodegradation in wet environments: a review. IAWA J. 21: 135-155.

Koch, G. 2004. Biologische und chemische Untersuchungen über Inhaltsstoffe im Holzgewebe von Buche (Fagus sylvatica L.) und Kirschbaum (Prunus serotina Borkh.) und deren Bedeutung für Holzverfärbungen. Mitt. BFH 216, Hamburg.

Koch, G., J. Bauch, \& J. Puls. 2003. Topochemical characterisation of phenolic extractives in discoloured beechwood (Fagus sylvatica L.). Holzforschung 57: 339-345.

Koch, G. \& C. Grünwald. 2004. Application of UV microspectrophotometry for the topochemical detection of lignin and phenolic extractives in wood fibre cell walls. In: U. Schmitt, P. Ander, J.R. Barnett et al. (eds.), Wood fibre cell walls: methods to study their formation, structure and properties: 119-130. Swedish University of Agricultural Sciences, Uppsala.

Koch, G. \& G. Kleist. 2001. Application of scanning UV microspectrophotometry to localise lignins and phenolic extractives in plant cell walls. Holzforschung 55: 563-567. 
Koch, G., H.G. Richter \& U. Schmitt. 2006. Topochemical investigation on phenolic deposits in the vessels of afzelia (Afzelia spp.) and merbau (Intsia spp.) heartwood. Holzforschung 60: 583-588.

Petréquin, P., R.M. Arbogast, C. Bourquin-Mignot, C. Lavier \& A. Viellet. 1998. Demographic growth, environmental changes and technical adaptations: responses of an agricultural community from the 32nd to the 30th centuries BC. World Archaeology 30: 181-192.

Rossi, S., T. Anfodillo \& R. Menardi. 2006. Trephor: a new tool for sampling microcores from tree stems. IAWA J. 27: 89-97.

Rowell, R.M. \& R. J. Barbour. 1990. Archaeological wood. Properties, chemistry, and preservation. Amer. Chem. Soc., Washington D.C.

Schmidt, O. 1980. Über den bakteriellen Abbau der chemisch behandelten verholzten Zellwand. Material u. Organismen 15: 207-224.

Schmidt, O. \& W. Liese. 1982. Bacterial decomposition of woody cell walls. Int. J. Wood Preserv. 2: 13-19.

Schmidt, O. \& W. Liese. 1994. Occurrence and significance of bacteria in wood. Holzforschung 48: 271-277.

Schmitt, U. \& P. Hoffmann. 1998. Zur Zellwandstruktur von 1600 Jahre altem, wassergesättigtem Eichenholz. Holz Roh- Werkst. 56: 211-212.

Schmitt, U., A.P. Singh, H. Thieme, P. Friedrich \& P. Hoffmann. 2005. Electron microscopic characterization of cell wall degradation of the 400,000-year-old wooden Schöningen spears. Holz Roh- Werkst. 63: 118-122.

Schniewind, J.I. 1990. Physical and mechanical properties of archaeological wood. In: R.M. Rowell \& R.J. Barbour (eds.), Archaeological wood. Properties, chemistry, and preservation: 87-109. Amer. Chem. Soc., Washington D.C.

Singh, A.P. \& J.B. Butcher. 1991. Bacterial degradation of wood cell walls: a review of degradation patterns. J. Inst. Wood. Sci. 12: 143-157.

Singh, A.P., Y.S. Kim, S.G. Wi, K.H. Lee \& I.J. Kim. 2003. Evidence of the degradation of middle lamella in a waterlogged archaeological wood. Holzforschung 57: 115-119.

Spurr, A.R. 1969. A low viscosity embedding medium for electron microscopy. J. Ultrastr. Res. 26: $31-43$.

Takabe, K., S. Miyauchi, R. Tsunoda \& K. Fukazawa. 1992. Distribution of guaiacyl and syringyl lignins in Japanese beech (Fagus crenata): variation within annual ring. IAWA J. 13: $105-112$.

Velušček, A. 2002. Ostanki eneolitskega voza z Ljubljanskega barja (The remnants of the Eneolithic cart from the Ljubljana Marshes). Arheološki Vestnik 53: 51-57.

Velušček, A. \& K. Čufar. 2002. Dendrokronološke raziskave kolišč na Ljubljanskem barju - stanje 2001 (Dendrochronological investigation into the pile-dwelling settlements of the Ljubljana Marshes - the situation in 2001). Arheološki Vestnik 53: 59-67. 